\title{
Assessment of Effect of Labour Strikes on Access to Service Delivery in Secondary Health Institutions in Cross River State, Nigeria
}

Article by Samson Olusegun Aturaka ${ }^{1}$, Amosu AM $^{2}$, Robert J. Chiegil ${ }^{2}$, Felix Sanni ${ }^{3}$, Musa Orenyi $^{4}$, Margaret Dakwat ${ }^{5}$, Abiodun Olaiya Paul ${ }^{6}$, Opeyemi Joseph ${ }^{7}$

${ }^{1}$ Texila American University, Department of Public Health, Guyana, South Amarica

${ }^{2}$ Department of Public Health, School of Allied Public and Allied Health, Babcock University, Ilishan Remo, Ogun State, Nigeria

${ }^{3}$ Department of Chemistry, Federal University of Agriculture, Abeokuta, Ogun State, Nigeria

${ }^{4}$ Department of Supply Chain Management and Operations, Axios Foundation Nigeria, Central Medical Store, EDP Compound Calabar, Nigeria

${ }^{5}$ Fhi 360 Department of Health system strengthening and Laboratory services, Country office, Abuja Nigeria

${ }^{6}$ Fhi 360 Department of Health system strengthening and Laboratory services, Country office, Abuja Nigeria

${ }^{7}$ Fhi360 AHNi, Benue State Office, Department of Health System Strengthening and Laboratory Services, Makurdi, Nigeria

${ }^{8}$ Fhi360, Cross River State Office, Department of Health System Strengthening and

Laboratory Services, Calabar, Nigeria

E-mail: segunhydd@yahoo.com (S.O.Aturaka)

\begin{abstract}
Frequent labour crisis leading to strikes is common in a developing country like Nigeria. This crosssectional descriptive study was carried out to assess the effect of labour strikes on access to service delivery in secondary Health Institutions in Cross River State, Nigeria. The 508 respondents were drawn from the outpatient, laboratory and pharmacy departments, Ante-Natal and Post-Natal and ART clinics of the 7 secondary health institutions spread across 3 senatorial districts in the state between January and February 2018. Data were collected with a semi structured, closed-and open-ended questionnaire. Raw data were entered EpiData ${ }^{\mathrm{TM}}$ and exported for analysis using the SPSS software version 20. The data were cleaned and validated for use. Frequency tables were produced and associations between categorical variables were determined using chi square test at a significance level of $P<0.05$.

The age range of most repondents was 25 - 45 with the peak value of 198 (39\%) recorded for age group 25 - 34 years. The results showed that though many people did not know the reasons why health workers embark on incessant strikes, they did not support strikes. Seven factors were highlighted as the major causes of regular strikes in Nigerian health institutions and the knowledge of respondents about all these factors were tested. Overall, the accessibility of patients to healthcare during labour strikes was approximately $8 \%$ which was not a pleasant experience for the patients. Conclusively, labour strike has serious effects on access to service delivery in secondary health institutions in Cross River State, Nigeria.
\end{abstract}

Keywords: Labour Strikes, Access to Service Delivery, Secondary Health Institutions, Healthcare Workers and patients' educational level

\section{Introduction}

In a developing country like Nigeria, frequent labour crisis leading to strikes is common. The health sector is not an exception to this trend. It is a multi-disciplinary sector comprising of many professionals like doctors, medical laboratory scientists, nurses and pharmacists to mention a few. Nigeria masses have suffered from frequent healthcare workers' strikes from 2012 to date from 2013 - 2015 witnessing several health worker's strikes involving all health professionals. Frequent healthcare workers' strikes 
result from the closure of public healthcare institutions preventing Nigerians' access to quality health services (Olerebe, 2016).

There are so many reasons health professionals go on strike. The main underlying causes of industrial action Nigeria include career stagnation, perceived discriminatory policies and demoralization from working in systems with poor infrastructure, manpower shortages and poor personal remuneration (Ogunbanjo, 2009). However, in recent times, there has been a divided opinion on true underlying factors responsible for the causes of industrial action (Botero, 2014).

From year 2012 to date, the Nigerian health system has experienced several labour strikes involving different health professional unions/associations like Nigerian Medical Association (NMA), National Association of Resident Doctors (NARD), Joint Health Workers Union of Nigeria (JOHESU) and National Union of Allied Health Professionals (NUAHP) to mention a few. These strikes have adversely impacted on the healthcare system, leading to several avoidable deaths, complications and outgoing medical tourism, as the wealthy seek health services abroad (Adebimpe, 2010). The outcome of these strikes is worst when they occur to periods of national health emergencies such as the recent suspected cases of Monkey pox disease outbreak of some part of the country, Ebola viral disease outbreak, Lassa fever or cholera outbreaks or even man-made emergencies like Militant killing and Boko Haram suicide bombings with mass casualties (Oleribe, 2016)

Strike is a strategy used by a group of employees to force the employer to meet their demands. Generally, strikes are discussed in terms of the economic nature of the events. A third-party involvement may ultimately pressurize the employees and employer to settle a strike. Frequent strikes by the health workers would affect the role and responsibilities for professionals in the health sector and ultimately leads to poor service delivery, low quality of care and client dissatisfaction.

Labour strikes is an aberration in the healthcare system, it impacts negatively on patients accessing healthcare delivery and discourages many patients from accessing health institution. Frequent health worker strikes reduce uptake of service delivery which might invariably result in the poor healthcare quality.

\section{Materials and methods}

Health care service in Cross River State is tiered into: Primary, Secondary and Tertiary. The State has 1114 primary health centres, 12 General Hospitals and 1 tertiary health institution. A cross-sectional descriptive survey approach was used to execute this study between January and February 2018. A pretested semi structured questionnaire with both closed-and open-ended questions was used to collect data for this study. Multistage sampling technique was employed in selecting 508 respondents. Using the sample size calculation formula for population less than ten thousand, (Olawuyi, 1996) sample size of 500 was calculated. Multistage sampling methods were employed from state ministry of health totaling 12 General hospitals. In stage one, 2 out of the 3 senatorial districts were selected by simple random sampling employing simple ballot in the two selected geopolitical zones. In stage two, 7 out of 9 secondary health facilities were selected from the 2 senatorial districts (Southern and Northern senatorial districts) by simple random sampling. In Stage three, questionnaires were distributed systematically to patients attending the following service delivery points: outpatient department, laboratory department, pharmacy department and ART clinic based on their client load. These were consenting patients above 18 years old attending the outpatient, laboratory and pharmacy departments, Ante-Natal, Post-Natal and ART clinics of the 7 secondary health institutions spread across 3 senatorial districts in the Cross River state, Nigeria, between January and February 2018. Data collected were cleaned and validated for use. Simple frequency tables were produced and associations between categorical variables were determined using Chi square test at a significance level of $\mathrm{P}<0.05$. Age, Gender, educational qualification, occupation and attendance at the facility were re-coded for the Chisquare analysis. Recoding of variables saw all participants grouped into male and female, graduates and non-graduates, married and single (with widows classified as singles) and attendance at the facility grouped into $<1$ year, $1-5$ years, $6-10$ years, $11-15$ years and $>15$ years. 


\section{Results}

\section{Demographics}

There were $265(52.2 \%)$ males and 243 (47.8\%) females with male: female ratio of 1.1:1. The most frequent age group was 25 - 34 with $198(39.0 \%)$ respondents followed by 125 (24.6\%) seen for age range $35-44$. There were $92(18.1 \%)$ participants in $18-24$ age group, $75(14.8 \%)$ for $45-54$ while the least value of $18(3.5 \%)$ was seen for 55 years and above. Majority of respondents $(466 ; 87.8 \%)$ were Christians, 49 (9.6\%) Muslims and $13(2.3 \%)$ were traditional religion worshippers. Also, 83 (16.3\%) of the respondents did not have formal education, 220 (43.3\%) were non-graduates while 205 (40.4\%) were University/college graduates. Most of the respondents, $199(39.2 \%)$ were self-employed followed by $153(30.1 \%)$ who were gainfully employed while $142(28.0 \%)$ and $14(2.7 \%)$ were unemployed and retired respectively. The age range of repondents was $25-45$ years (Table 1).

Table 1. Socio-demographic characteristics of study participants

\begin{tabular}{|c|c|c|}
\hline Parameter & Frequency & Percentage \\
\hline $\begin{array}{l}\text { Gender } \\
\text { Male } \\
\text { Female }\end{array}$ & $\begin{array}{l}265 \\
243\end{array}$ & $\begin{array}{l}52.2 \\
47.8\end{array}$ \\
\hline $\begin{array}{l}\text { Marital status } \\
\text { Single } \\
\text { Married }\end{array}$ & $\begin{array}{l}248 \\
260\end{array}$ & $\begin{array}{l}48.8 \\
51.2\end{array}$ \\
\hline $\begin{array}{l}\text { Religion } \\
\text { Christianity } \\
\text { Islam } \\
\text { Traditional }\end{array}$ & $\begin{array}{l}446 \\
49 \\
13\end{array}$ & $\begin{array}{l}87.8 \\
9.6 \\
2.6\end{array}$ \\
\hline $\begin{array}{l}\text { Level of education } \\
\text { No formal education } \\
\text { Non-graduate } \\
\text { Graduate }\end{array}$ & $\begin{array}{l}83 \\
220 \\
205\end{array}$ & $\begin{array}{l}16.3 \\
43.3 \\
40.4\end{array}$ \\
\hline $\begin{array}{l}\text { Employment status } \\
\text { Unemployed } \\
\text { Employed } \\
\text { Self employed } \\
\text { Retired }\end{array}$ & $\begin{array}{l}142 \\
153 \\
199 \\
14\end{array}$ & $\begin{array}{l}28.0 \\
30.1 \\
39.2 \\
2.7\end{array}$ \\
\hline
\end{tabular}


DOI: $10.21522 /$ TIJPH.2013.06.02.Art011

ISSN: $2520-3134$

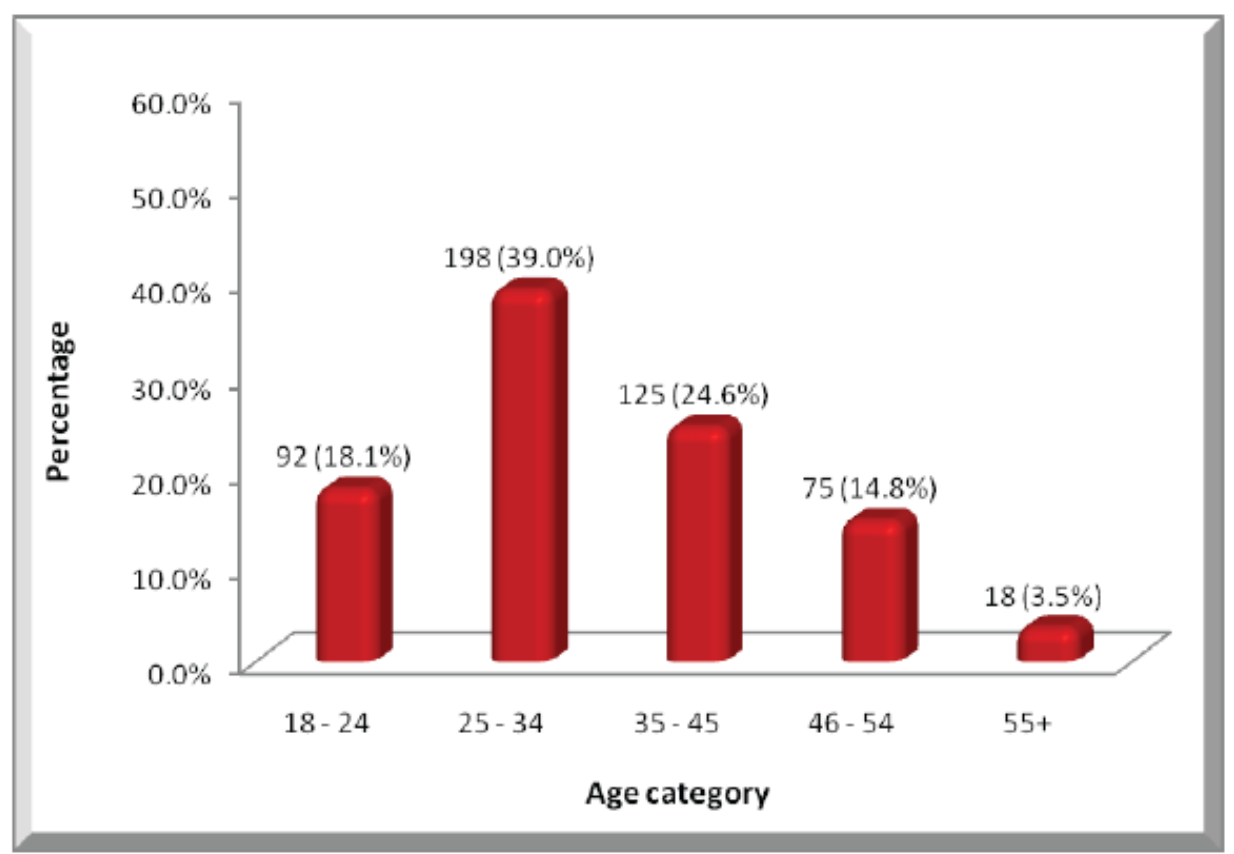

Figure 1. Age category of respondents

The age range of most repondents was 25 - 45 with the peak value of 198 (39\%) recorded for age group 25 - 34 years followed by $125(24.6 \%)$ for $35-45,92(18.1 \%)$ was seen for $18-24$ years, 75 $(14.8 \%)$ for $46-54$ while the least value of $18(3.5 \%)$ was seen for 55 years and above age group.

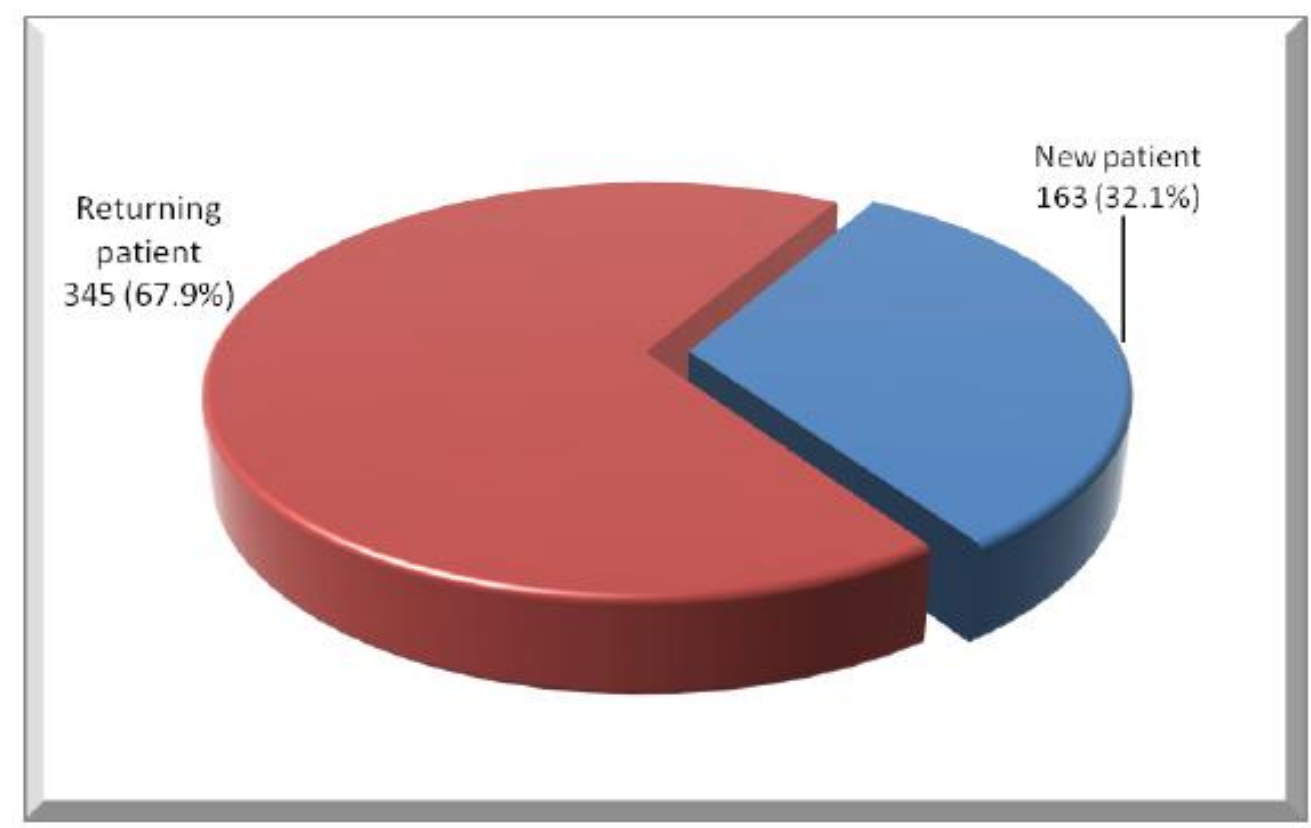

Figure 2. Patient's attendance status

More than half of the respondents were returning patients in their respective healthcare institutions, $345(67.9 \%)$ while $163(32.1 \%)$ were new patients at the time of interview.

About $87(17.1 \%)$ were in the hospital for the first time during while $421(82.9 \%)$ have been visited the hospital more than once before the day of interview. 


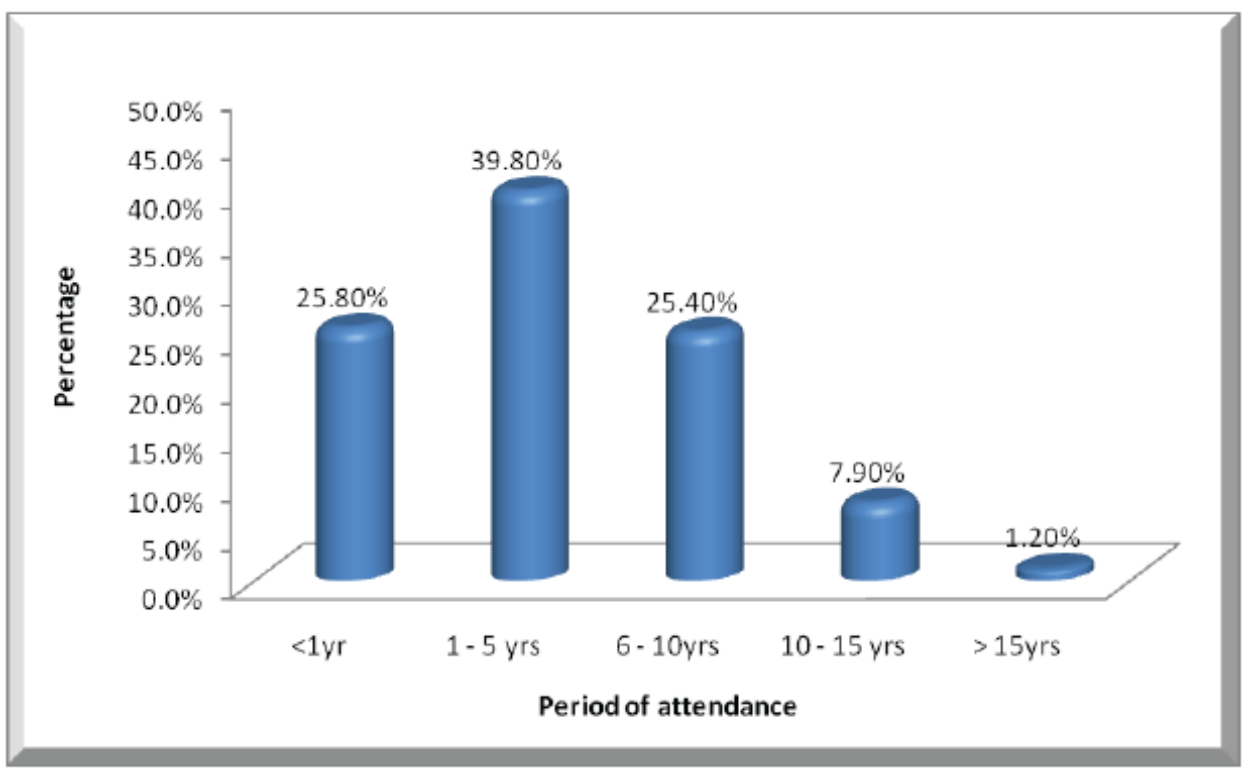

Figure 3. Period of hospital attendance

Approximately $40 \%$ of the respondents have been attending their respective hospitals for $1-5$ years, $25.8 \%$ have been attending for less than a year, $25.4 \%$ for $6-10$ years while $7.9 \%$ and $1.2 \%$ have been attending the hospital for $10-15$ years and more than 15 years respectively.

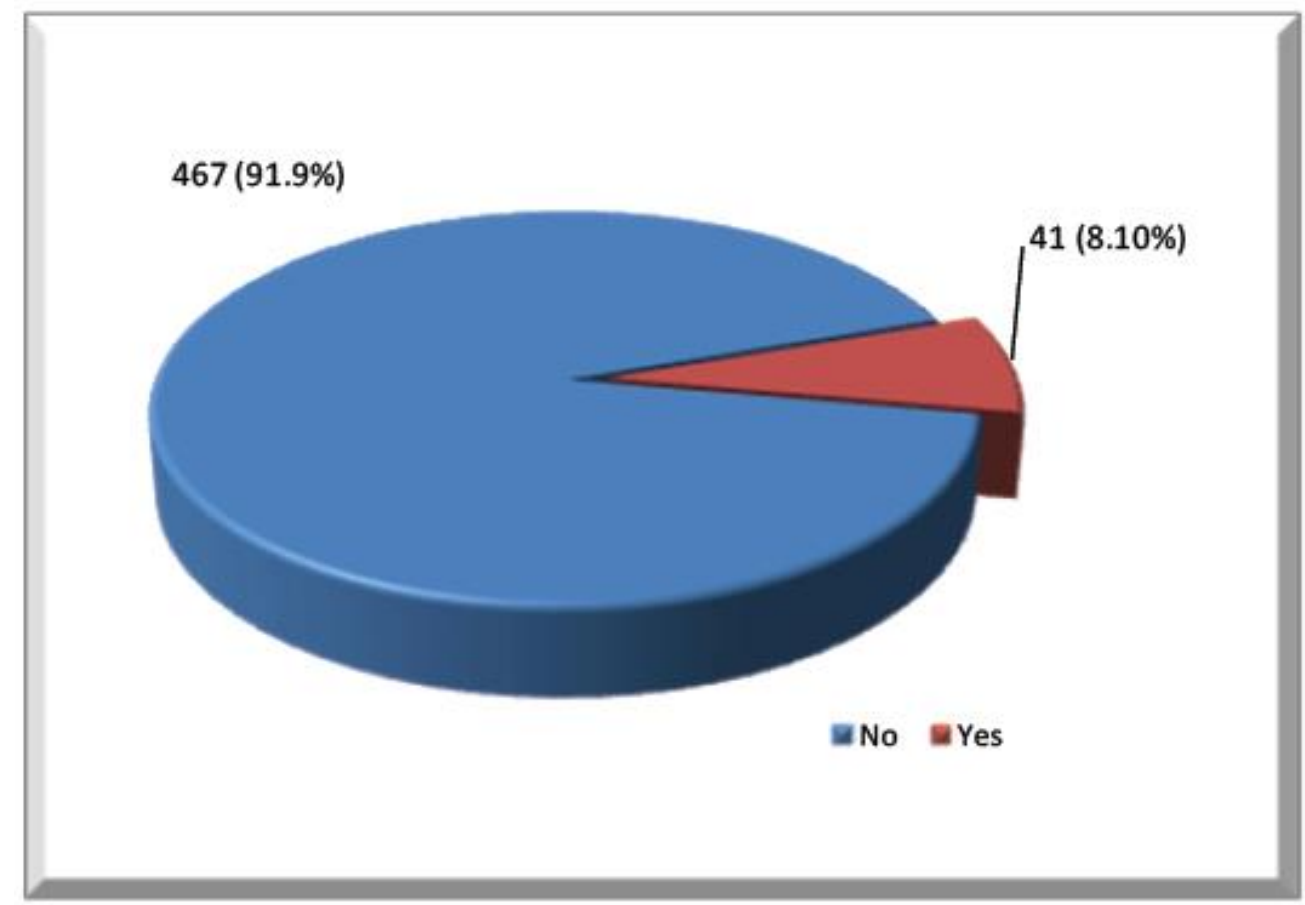

Figure 4. Do you support strike in our health institutions?

467 (91.9\%) respondents did not support strikes while just 41 (8.1\%) did. 
DOI: $10.21522 /$ TIJPH.2013.06.02.Art011

ISSN: $2520-3134$

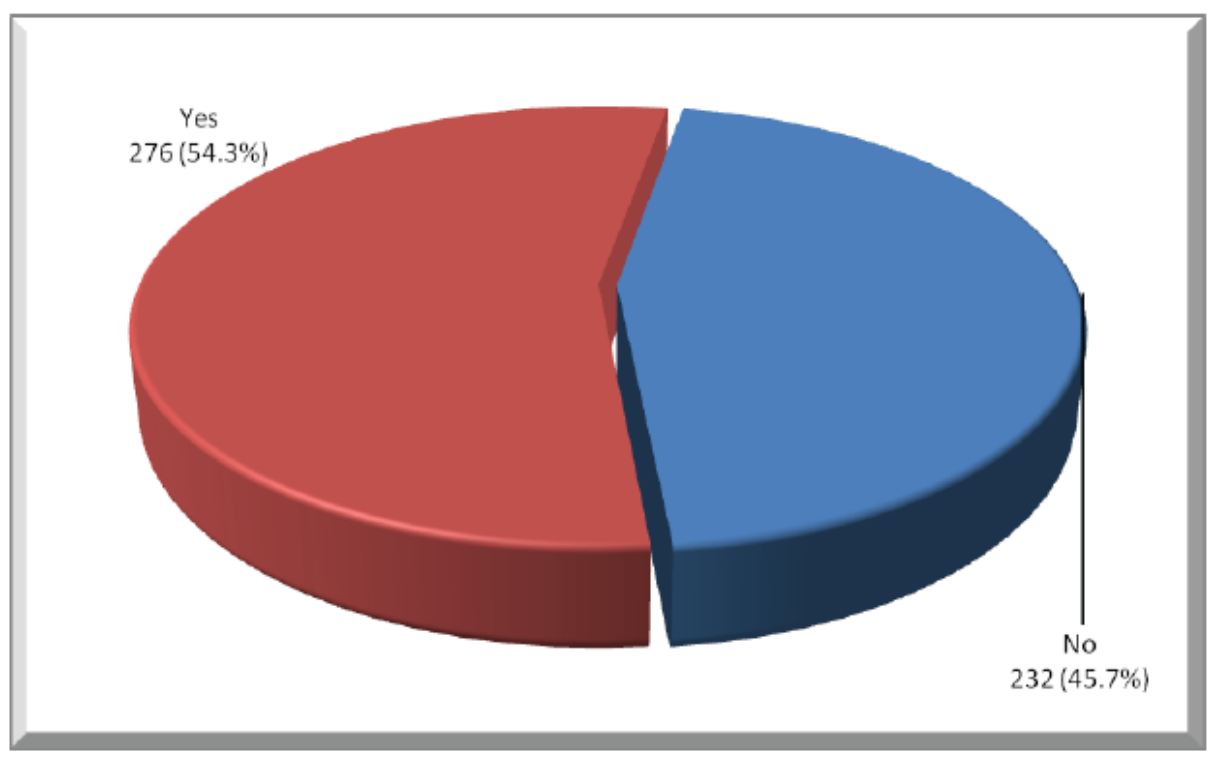

Figure 5. Do you know the reason for frequents strikes?

$276(54.3 \%)$ respondents knew the reasons for frequent labour strikes while $232(45.7 \%)$ said no

Table 2. Highlights of the major causes of strike

\begin{tabular}{llll}
\hline Parameter & Yes & No & Not sure \\
\hline $\begin{array}{l}\text { Bad Leadership/Management } \\
\begin{array}{l}\text { Inter-professional } \\
\text { disagreements }\end{array}\end{array}$ & $379(74.6 \%)$ & $88(19.5 \%)$ & $30(5.9 \%)$ \\
$\begin{array}{l}\text { Demand for higher } \\
\text { salary/wages }\end{array}$ & $312(61.4 \%)$ & $162(31.9 \%)$ & $34(6.7 \%)$ \\
$\begin{array}{l}\text { Inadequate funding of health } \\
\text { institutions }\end{array}$ & $450(88.6 \%)$ & $44(8.7 \%)$ & $14(2.8 \%)$ \\
$\begin{array}{l}\text { Inadequate tools/poor working } \\
\text { conditions }\end{array}$ & $356(70.1 \%)$ & $118(23.2 \%)$ & $34(6.7 \%)$ \\
$\begin{array}{l}\text { Failure to fulfill promises by } \\
\text { Government }\end{array}$ & $384(75.6 \%)$ & $99(19.5 \%)$ & $25(4.9 \%)$ \\
\begin{tabular}{l} 
Poor infrastructure \\
\hline
\end{tabular} & $359(70.7 \%)$ & $119(23.4 \%)$ & $30(5.9 \%)$ \\
\hline
\end{tabular}

$379(74.6 \%)$ accepted that bad leadership or bad hospital management is one of the causes of regular health workers' strikes, $88(19.5 \%)$ and 30 (5.9\%) said no and unsure respectively. On whether interprofessional disagreements are one of the factors that warrant health workers' strikes, $312(61.4 \%)$ said yes, $162(31.9 \%)$ said no while 14 (2.8\%) were not sure. Many of the respondents, $411(80.9 \%)$ were fully aware that demand for higher salaries is one of the major causes of strike while 44 (8.7\%) said no and $14(2.8 \%)$ were not sure. Inadequate funding of health institutions is one of the reasons why health workers embark on strikes, when tested, $411(80.9 \%)$ of the patients said yes, $76(15.0 \%)$ said no and $21(4.1 \%)$ were unsure. $356(70.1 \%)$ of the respondents were aware that inadequate tools/poor working conditions is one of the common bone of contention between government and health workers, which usually result to strikes. Yet 118 (23.2\%) were ignorant of this while $34(6.7 \%)$ were unsure. Failure by Government to fulfill promises made for health workers is another cause of regular strikes in health institutions, $384(75.6 \%)$ respondents were aware of this while $99(19.5 \%)$ said no and $25(4.9 \%)$ were not sure. $359(70.7 \%)$ said poor infrastructure in health institutions is one of the causes of strikes while $110(23.4 \%)$ said no and $30(3.5 \%)$ couldn't give specific answer. 


\section{Patients' access to healthcare services during strike}

Majority of the respondents (92.3\%) were unable to gain access to hospitals during strikes. Likewise, 94.5\% reported that no health worker was available to attend to them. $96.3 \%$ did not have access to laboratory services, $89.8 \%$ could not secure service in hospital pharmacies, $93.3 \%$ could not receive treatments because doctors and nurses were not available and $89.8 \%$ were unhappy attending hospitals during strikes. In overall, patient's access to healthcare services in government health institutions during strike is just $7.9 \%$. The chi square $\mathrm{P}$ value $<0.005$ negates the initial hypothesis that strike does not affect patients' access to health care services (Table 3 ).

Table 3. Access to healthcare during strike $(P=0.000)$

\begin{tabular}{|c|c|c|}
\hline Parameter & Yes & No \\
\hline $\begin{array}{l}\text { Were you able to gain access to the } \\
\text { hospital? }\end{array}$ & $39(7.7 \%)$ & $469(92.3 \%)$ \\
\hline Did health workers attend to you? & $28(5.5 \%)$ & $480(94.5 \%)$ \\
\hline $\begin{array}{l}\text { Did you meet a laboratory staff and being } \\
\text { attended to? }\end{array}$ & $19(3.7 \%)$ & $489(96.3 \%)$ \\
\hline $\begin{array}{l}\text { Do you meet a pharmacy staff and you were } \\
\text { you attended? }\end{array}$ & $52(10.2 \%)$ & $456(89.8 \%)$ \\
\hline Did you see any Doctor/Nurse working? & $34(6.7 \%)$ & $474(93.3 \%)$ \\
\hline Were you able to carry out laboratory tests? & $47(9.3 \%)$ & $461(90.7 \%)$ \\
\hline Were you able to collect all your drugs? & $52(10.2 \%)$ & $456(89.8 \%)$ \\
\hline $\begin{array}{l}\text { Will you be happy to come to this health } \\
\text { facility during strikes? }\end{array}$ & $52(10.2 \%)$ & $456(89.8 \%)$ \\
\hline Overall & $7.9 \%$ & $92.1 \%$ \\
\hline
\end{tabular}

Table 4. Awareness of causes of labour strikes with level of education $(\mathrm{P}=0.000)$

\begin{tabular}{l|lll}
\hline $\begin{array}{l}\text { Aware of reasons } \\
\text { for frequent } \\
\text { strikes }\end{array}$ & \multicolumn{3}{|l}{ Level of Education $(\%)$} \\
\cline { 2 - 4 } & $\begin{array}{l}\text { No formal } \\
\text { education }\end{array}$ & Non-graduate & Graduate \\
\hline Yes & $38(45.8 \%)$ & $97(44.1 \%)$ & $141(68.8 \%)$ \\
No & $45(54.2 \%)$ & $123(55.9 \%)$ & $64(31.2 \%)$ \\
Total & $83(100.0 \%)$ & $220(100.0 \%)$ & $\begin{array}{l}205 \\
(100.0 \%)\end{array}$ \\
\hline
\end{tabular}

Awareness of the causes of industrial actions is higher among graduates, $68.8 \%$ than $44.1 \%$ and $45.8 \%$ recorded for non-graduates and the group with no formal education respectively. The percentage of those that have no knowledge of causes of strikes is higher among non-graduates (55.9\%) than among group with no formal education $(52.2 \%)$ but the value seen for graduates is below thirty two percent $(31.2 \%)$. 
DOI: $10.21522 /$ TIJPH.2013.06.02.Art011

ISSN: $2520-3134$

Table 5. Awareness of causes of labour strikes with age $(\mathrm{P}=0.000)$

\begin{tabular}{|c|c|c|c|c|c|}
\hline \multirow{2}{*}{$\begin{array}{l}\text { Aware of } \\
\text { reasons for } \\
\text { frequent } \\
\text { strikes }\end{array}$} & \multicolumn{5}{|c|}{ Age Category (\%) } \\
\hline & $18-24$ & $25-34$ & $35-44$ & $45-54$ & $55+$ \\
\hline Yes & $36(39.1 \%)$ & $99(50.0 \%)$ & $75(60.0 \%)$ & $55(73.3 \%)$ & $11(61.1 \%)$ \\
\hline No & $56(60.9 \%)$ & $99(50.0 \%)$ & $50(40.0 \%)$ & $20(26.7 \%)$ & $7(38.9 \%)$ \\
\hline Total & $92(100.0 \%)$ & $198(100.0 \%)$ & $125(100.0 \%)$ & $75100.0 \%$ ) & $18(100.0 \%)$ \\
\hline
\end{tabular}

Percentage awareness was $39.1 \%$ among $18-24$ years age group, for $25-34$, the percentage increased to $50 \%$, higher percentage was seen for $35-45$ with $60 \%$, for $45-54$, it was $73.3 \%$ while the percentage dropped to $61.1 \%$ for group of over 55 years of age but still higher than the younger age group of $10-34$ years old.

Table 5b. Pairwise comparison of age based on awareness of causes of strike

\begin{tabular}{lllll}
\hline Age Category 1 & Age Category 2 & Mean diff. & Std. Error & P value \\
\hline $18-24$ & $25-34$ & -0.109 & 0.062 & 0.079 \\
& $35-44$ & $-0.209^{*}$ & 0.067 & 0.002 \\
& $45-54$ & $-0.342^{*}$ & 0.076 & 0.000 \\
& $55+$ & -0.220 & 0.126 & 0.082 \\
\hline $25-34$ & $35-44$ & -0.100 & 0.056 & 0.074 \\
& $45-54$ & $-0.233^{*}$ & 0.066 & 0.000 \\
& $55+$ & -0.111 & 0.120 & 0.357 \\
\hline $35-44$ & $45-54$ & -0.133 & 0.071 & 0.063 \\
& $55+$ & -0.011 & 0.123 & 0.928 \\
\hline $45-54$ & $55+$ & 0.122 & 0.128 & 0.342 \\
\hline
\end{tabular}

The mean difference is significant at the 0.05 level.

There is no statistical difference in the level of awareness of the causes of strike between age groups $18-24$ and $25-34,18-24$ and 55+, $25-34$ and $35-44,25-34$ and 55+, $35-44$ and 55+, $45-54$ and 55+ $(\mathrm{P}>0.05)$. However, the level of awareness is higher among $35-44$ and $45-54$ than among 18 -24 . Likewise, awareness level is higher among $45-54$ than $25-34(\mathrm{P}<0.05)$. In overall, the highest level of awareness is seen for $45-54$ age group while the least awareness is seen for $18-24$ age group.

Table 6. Awareness of causes of labour strike with support for strike $(P=0.004)$

\begin{tabular}{|c|c|c|}
\hline \multirow[t]{2}{*}{ Do you support strikes? } & \multicolumn{2}{|c|}{$\begin{array}{l}\text { Do you know the reason for frequents } \\
\text { strikes? }(\%)\end{array}$} \\
\hline & Yes & No \\
\hline Yes & $31(11.2 \%)$ & $10(4.3 \%)$ \\
\hline No & $245(88.8 \%)$ & $222(95.7 \%)$ \\
\hline Total & $276(100.0 \%)$ & $232(100.0 \%)$ \\
\hline
\end{tabular}


$88.8 \%$ of those who know the reasons for frequent labour strikes in health institutions do not support strike while $11.2 \%$ support strike. (95.7\%) do not know the reasons for strikes and yet did not support strikes while $4.3 \%$ of those who do not know the reasons for strike support strikes.

Table 7. Access to healthcare/service delivery during labour strike $(\mathrm{P}=0.000)$

\begin{tabular}{|c|c|c|}
\hline Parameter & Yes & No \\
\hline Were you able to gain access to the hospital? & $39(7.7 \%)$ & $469(92.3 \%)$ \\
\hline Did health workers attend to you? & $28(5.5 \%)$ & $480(94.5 \%)$ \\
\hline $\begin{array}{l}\text { Did you meet a laboratory staff and being } \\
\text { attended to? }\end{array}$ & $19(3.7 \%)$ & $489(96.3 \%)$ \\
\hline $\begin{array}{l}\text { Do you meet a pharmacy staff and you were } \\
\text { you attended? }\end{array}$ & $52(10.2 \%)$ & $456(89.8 \%)$ \\
\hline Did you see any Doctor/Nurse working? & $34(6.7 \%)$ & $474(93.3 \%)$ \\
\hline Were you able to carry out laboratory tests? & $47(9.3 \%)$ & $461(90.7 \%)$ \\
\hline Were you able to collect all your drugs? & $52(10.2 \%)$ & $456(89.8 \%)$ \\
\hline $\begin{array}{l}\text { Will you be happy to come to this health } \\
\text { facility during strikes? }\end{array}$ & $52(10.2 \%)$ & $456(89.8 \%)$ \\
\hline Overall & $7.9 \%$ & $92.1 \%$ \\
\hline
\end{tabular}

$92.3 \%$ were not able to gain access to hospitals during strikes while only $7.7 \%$ could. Only $5.5 \%$ said health workers attended to them during strikes while $94.5 \%$ were not attended to. $96.3 \%$ could not see staff to attend to their needs in laboratories while only $3.7 \%$ were able to gain attention. Only $10.2 \%$ said they met pharmacy staff and were attended to while $89.8 \%$ did not meet them. $6.7 \%$ saw Doctors/Nurses working during strikes while $93.3 \%$ did not. Only $9.3 \%$ could carry out laboratory tests while $90.7 \%$ could not. $10.2 \%$ could collect all their drugs while $89.8 \%$ could not. $10.2 \%$ will be happy coming to health institutions during strikes while $89.8 \%$ will not.

Table 8. Effect of access to service delivery during laboour strikes $(\mathrm{P}=0.000)$

\begin{tabular}{lll}
\hline Parameter & Yes & No \\
\hline $\begin{array}{l}\text { Do you go to private hospital during } \\
\text { strikes? }\end{array}$ & $384(75.6 \%)$ & $124(24.4 \%)$ \\
$\begin{array}{l}\text { Do you spend more money? } \\
\begin{array}{l}\text { Do you agree that there is disruption in } \\
\text { patients care? }\end{array}\end{array}$ & $375(73.8 \%)$ & $133(26.2 \%)$ \\
$\begin{array}{l}\text { Do you agree that there is high rate of } \\
\text { referral of patients to private hospitals } \\
\text { during strike? }\end{array}$ & $339(66.7 \%)$ & $169(33.3 \%)$ \\
\hline
\end{tabular}

$384(75.6 \%)$ do go to private hospitals for treatment during strikes while only $124(24.4 \%)$ do not. $374(73.8 \%)$ spend more money during strike wile $133(26.2 \%)$ do not. $399(66.7 \%)$ said there is disruption in patients' care during strike while 169 (33.3\%) said no. 397 (78.1\%) said there is high rate of referral during strikes while 111 (21.9\%) said no. 
DOI: $10.21522 /$ TIJPH.2013.06.02.Art011

ISSN: $2520-3134$

\section{Discussion}

Access to healthcare/service delivery during strike revealed a vital finding from the present study in that all the variables agreed to the fact that strike has effect on access to service delivery with all parameters having less than $10.5 \%$. This finding is a pointer to the poor health care quality during strikes (Ogunbanjo et al, 2009) and it also lay credence to the fact that many lives are lost during strikes action as hospital gates are under lock and key with few health workers attending to emergencies (Adebimpe et al, 2010). Health worker abandoned their duty post leading to sudden disruption in service delivery with many in-patients not completing their medication before discharged with no access to drugs and laboratory services for monitoring of their health conditions during strikes. Retention and adherence to drugs are very low since patients could not continue with medication as they could not have access to the pharmacy or laboratory to monitor their health condition. Low access to service delivery in government health institution sent many patients to private hospitals, traditional birth attendants and herbalist alike, it also encouraged medical tourism outside the country by the rich and people in government who can afford cost (Safiya, 2015). Hence, it is evidence from the outcome of the study $(10.2 \%)$ that patients are not happy coming to health facility during strikes. This is evidently clear that patients are not satisfy and unhappy during strike actions to access health institutions during strike knowing fully well that there will be no service delivery or at best only skeletal services. This study focused mainly on secondary health institutions in Cross River State which is not enough to generalize it to Nigeria. Subsequent study will need to focus on the whole health institution in Nigeria which include primary health care and tertiary health institutions.

\section{Conclusion}

Health care workers especially facility staff in in essential services like accidents and emergency section, laboratory and pharmacy sections need to demonstrate favourable attitude towards a looming strike by making sure that patients have access to services delivery and there is access to health commodities especially drugs and laboratory services during strike to improve quality of care in our health institution. In conclusion, labour strike has serious effects on access to service delivery in secondary health institutions and all effort should be in place to reduce the effect on service delivery.

\section{References}

[1]. Adebimpe WO, Owolade OA, Adebimpe MA. (2010). Health worker's perception of the use of strikes as a tool for dispute resolution in Lagos State, Nigeria SocSci Public Policy. 2010; 2: 19-23.

[2]. Adesina, J.O (2003). Labour Policies of a Neo-Fuhrer State: the Nigerian Case, Annals of the Social Science Academy 14(15):49-66.

[3]. Adeyemi, T.O. (2009). Principals' Management of Conflicts in Public Secondary Schools in Ondo State, Nigeria: A Critical Survey. Education Research and Review, 4 (9): 418-426.

[4]. Botero JC, Djankov S, La Porta R, López de Silanes F, Shleifer A. (2004). The Regulation of Labor. The Quarterly Journal of Economics. 2004; 119(4):1339-82. doi: 10.1162/0033553042476215. http://qje.oxfordjournals.org/content/119/4/1339.full.pdf+html.

[5]. Bloomsbury, G. (2002). A strategy for Industrial relations in Great Britain, Britain Journal of Industrial Relations 10(20):12-20.

[6]. Chima, O (2010). Nigerian Health Watch. Patients suffer as Nigerian healthcare workers continue strikes; who cares? Wednesday, 25 August 2010.

[7]. Dauda, Y.A (2007). Employment of Independent Arbitrators in the Management of Trade Disputes and Industrial Crisis in Nigeria. Nigerian Journal of Labour Law and Industrial Relations, 1(1):26-44.

[8]. Davies A, Rotimi A.D., Adenike A.O, Asa A, Adedapo A, Muktar G, Jacob K.O, Oluwafemi O, and Alexander I.(2017), Health workforce and governance: the crisis in Nigeria, Hum Resour Health. 2017; 15: 32.

[9]. Encyclopedia of the Nations. Nigeria-working conditions [Online]. (n.d); http://www.nationsencyclopedia.com/economies/Africa/Nigeria-WORKING-

CONDITIONS.html\#ixzz3Q0J8zoCc. Accessed 10 Apr 2015.

[10]. Fajana, S. (2000). Industrial Relations in Nigeria: Theory and Features 2ed, Lagos: Labofin\& Co.

[11]. Fashoyin, T. (1992). Industrial Relations in Nigeria, $2^{\text {nd }}$ Edition, Ikeja: Longman Ltd. 
Texila International Journal of Public Health Volume 6, Issue 2, Jun 2018

[12]. Fashoyin T. (2008). Management of disputes in the public service, southern African Journal of Industrial Relations 50(40):578-594.

[13]. George Padmore (2015). The voice of coloured labour; speeches and reports of colonial delegates to the World Trade Union Conference, Manchester, PANAF Services Ltd. 1945; Available from https://www.marxists.org/archive/padmore/1945/labour-congress/. Accessed 10 Apr 2015.

[14]. IBM Corp. IBM SPSS Statistics for Windows, Version 20.0. Armonk: IBM Corp; 2012.

[15]. Keating NL, Green DC, Koa AC, Gazmararian JU, Wu VY and Cleary PD (2002): How are patients' specific ambulatory care experiences related to trust, satisfaction and considering changing physicians, Gen Intern Med 17 (1): $29-39$.

[16]. Lauritsen JM. (2015) editor. EpiData data entry, data management and basic statistical analysis system. Odense Denmark, EpiData Association, 2000-2008. Http://www.epidata.dk. Accessed 13 Apr 2015.

[17]. Ogunbanjo G.A. and Knapp van Bogaert D. (2009), Doctors and strike action: can this be morally justifiable? S AfrFamPract. 2009; 51(4):306-8. doi: 10.1080/20786204.2009.10873869.

[18]. Olawuyi, J.F (1996).Choosing the study subjects and sampling. In biostatistics, a foundation course in health sciences. First edition. Yotson consult publishers Ibadan, 110-118.

[19]. Oleribe OO, Ezieme IP, Oladipo O, Akinola EP, Udofia D, Taylor-Robinson SD. Industrial action by healthcare workers in Nigeria in 2013-2015: an inquiry into causes, consequences and control-a cross-sectional descriptive study. Hum Resour Health. 2016; 14(1):46. doi: 10.1186/s12960-016-0142-7. [PMC free article][PubMed][Cross Ref].

[20]. Otobo, D. (2000). Industrial Relations Theory and Controversies. Lagos: Malthouse Press.

[21]. Orr, R. D., N. Pang, E. D. Pellegrino, and M. Siegler. (1997). "Use of the Hippocratic Oath: A Review of Twentieth-Century Practice and a Content Analysis of Oaths Administered in Medical Schools in the U.S. and Canada in 1993." The Journal of Clinical Ethics 8 (Winter): 377-388.

[22]. Rennie S. (2009). An epidemic of health care worker strikes. Lagos: Global consult.

[23]. Safiya I. Dantiye (2015), Strike: Nigerians at the mercy of health workers, doctors.

[24]. safiyadantiye@ dailytrust.com | Publish Date: Jan 2, 2015 4:00AM.

[25]. Stelfox HT, Ghandi TK, Orav EJ, and Gustafson ML (2005): The relation of patient satisfaction with complaints against physicians and malpractice law suits. Am J Med 118 (10): 1126 - 33.

[26]. Stuart, K. (2010). Professionalism and healthcare strikes. South African, Journal of Bioethics and Law 3(1):14-2. 